Article

\title{
The Impact and Determinants of Environmental Taxation on Economic Growth Communities in Romania
}

\author{
Jean Andrei ${ }^{1, *}$, Mihai Mieila ${ }^{2}$, Gheorghe H. Popescu ${ }^{3}$, Elvira Nica ${ }^{4}$ and Manole Cristina ${ }^{4}$ \\ 1 Petroleum-Gas University of Ploiesti, 39 Bucuresti Blvd., Prahova 100680, Romania \\ 2 Valahia University of Targoviste, Aleea Sinaia Street, No. 13, Targoviste, Dambovita 130004, Romania; \\ m_mieila@yahoo.com \\ 3 Dimitrie Cantemir Christian University, 176 Splaiul Unirii, Bucharest 030134, Romania; \\ popescu_ucdc@yahoo.com \\ 4 Bucharest University of Economic Study, 6 Roman Place, Bucharest 010374, Romania; \\ popescu_elvira@yahoo.com (E.N.); cristina_manole68@yahoo.com (M.C.) \\ * Correspondence: ajvasile@upg-ploiesti.ro; Tel.: +40-721-146-587 \\ Academic Editor: Ignacio de los Ríos Carmenado \\ Received: 17 August 2016; Accepted: 25 October 2016; Published: 1 November 2016
}

\begin{abstract}
Environmental taxation represents a key influence on sustainable development in post-transition countries. Romania has experienced important transformations of environmental policy, including taxation, due to sustained reliance on traditional energy sources to satisfy its energy needs. The aim of this paper is to show a possible causal relationship between the Romanian GDP and several explanatory variables related to taxation of environmental damage and energy generation and consumption in the country. In order to do this, the authors make use of several statistical tests to verify the existence of a meaningful relationship between economic variables expressed in time series. The study has also attempted to identify the influence of environmental taxation on ensuring green economic development, starting from the premise that for emergent economies these taxes provide both a GDP increase and prevent environmental degradation by decreasing the pollution and environmentally harmful supplies and practices.
\end{abstract}

Keywords: energy; renewables; environment; taxation; development; emergent economy; economic growth

\section{Introduction}

In modern economies, the energy represents a key factor in ensuring of the sustainable development for the whole society. As there has been proven over time, modern economies are largely dependent on energy, which significantly contributes to the development of the current life standard, revolutionizing the transportation, communications, and industry, creating premises for raised productivity levels. For the countries in the European Union, the energy taxation and fiscal policy for energy represent key components in reducing pollution and in applying of the Kyoto Protocol requirements [1-3].

On the other hand, the tax burden on energy production and consumption involves additional costs, both for business and households, which are already struggling with high levels of taxation. The competitiveness of the industrial sector and of the entire economy is directly and significantly affected by energy taxation. Taking into account that the energy represents a heterogenous commodity, the associated fiscal policy has to reflect this diversification, both through considered quotas and the specific application forms. Therefore, the European fiscal policy in the field has been designed with the 
aim of functionality, in order to contribute to the efficient use of available energy resources, helping to settle potential issues in supply, preventing wastage and unsustainable consumption of resources.

Generally, an inadequate tax policy in the field of energy may lead to a distorted or even uncompetitive allocation of resources in the economy, which would result in an unnecessary increase of the production prices, implying decrease in national production, depressing competitiveness and the investments. In the literature, energy tax policies are severely criticized as being strongly distributive [4-6]. The tax burden on fuels production and consumption affect the consumers' standard of living in different manners; the major drawback of this policy approach is that the most affected are people and households with low levels of income.

On the other hand, in the lliterature [7-12], is a widely emphasized that the taxation represents an essential stimulus towards the optimal use of resources (including the energy ones), concomitant with reduction in greenhouse gas emissions. As a result, numerous studies [13-18] tried to evaluate the link between the energy taxation on the one hand, and economic growth, or occupation, on the other hand.

In this context, some researches revealed that use of some green tax has a direct impact on reduction in emissions and in increasing of the general economic output concomitant with reducing of the income gap between different social categories, and granting social welfare [19]. Further on, researches in the field proved that the relationship between capital investments and energy tax rates is not significant [19]. Other studies tried to develop new methodological approaches in order to evaluate the financial effects of environmental taxation [20,21].

The influence of fiscal policy towards the evolution of the national economy, production and consumption structures, investments and the promotion of environmental-friendly and energy-efficient technologies are common topics in current scientific debate. Thus, since 1920, the literature has expressed a wide range of opinions: some authors have argued for taxation of pollution and internalization of the associated costs, resulting of a Pegouvian tax [22]; in other views, the energy consumption has to be treated as a contributive factor in increasing pollution. Other studies proved that fuel taxation is highly progressive in contemporary economies, as in the cases of the United States or Austria [23]. In this field exists a plethora of approaches: some consider only the gasoline consumption and the associated fees [24]; other argue that in the US's case the economy faces an opposite phenomenon, at least in households with high incomes [6]; not least, some researches try to evaluate the variation in taxation across countries and the subsequent consequences, based on data provided by the Statistical Office of the European Union (Eurostat) [24,25].

If the altering of industrial competitiveness represents a certain short-run effect of environmental taxation, in the long run, the diversity of the promoted environment policies have proved different but significant effects on the structure of the national economy, helping to reduce carbon emissions, carbon intensity and energy consumption [26-28]. In the literature [10], it is also claimed that the taxation of energy consumption and associated fees can be aimed both towards internalizing of the costs associated to the greenhouse emissions, and reducing of these emissions [10].

In this context, the main objective of this paper is the analysis of the impact and determinants of environmental taxation on economic growth communities in Romania by analyzing the effects of this policy on the national economic paradigms.

\section{Materials and Methods}

The main research feature of this article is the use of Granger causality tests [29], trying to evaluate the causal relationship between environmental taxes and various measures of energy production and consumption in Romania, on the one hand, and economic growth, on the other hand. to the author's best knowledge, this represents the first attempt in using of the Granger causality tests in studying of the causal relationship between environmental taxes and various measures of energy production and consumption in Romania.

In studying the direction of causal relations between a set of variables, Granger causality tests have been extensively employed with positive outcomes. As has been proven in the literature [28-30], 
if there is co-integration in a pair of series that are integrated of order one, $I(1)$, there must be causation in at least one direction. Starting from this assumption, this appears to be a result of the presence of cointegration, implying that an error correction model can be formed, of which the error correction term has a significant effect on the dependent variable. Moreover, in the literature it has been proven that the inter-linkages between the energy sector and the economic performance are dependent to a great extent on the development level and economic structure of the considered countries [30-35].

As a reflection of its importance for the European Union objectives, the environmental taxation represents a well-defined and independent policy domain. According to the Maastricht Treaty (1992) the regulations in this field are adopted by the European Commission and not by the member states. To carry out the present research objectives, the environmental taxation approach has been employed consistent with the Eurostat definition, applied at the EU-28 level, including Romania. According to the official statistics definition [36] and to the specific literature approaches [37-39] an environmental tax is considered to be any type of tax which covers an impaired perception of the environment, whose application is intended to limit or reduce a harmful effect.

Following the Eurostat framework, the considered datasets are represented by environmental tax revenues calculated as a proportion of GDP (Table 1). The environmental tax revenues consist of various taxes, such as taxes on transportation and energy products, vehicle excise duty, the value-added tax applied to petroleum, and the air passenger duty. The taxes refer to both one-off and recurrent taxes, such as sales of equipment and road tax, respectively. In the first stage, the European countries designed the fuel taxes on energy and transportation as energy measurements (to decrease dependence on petroleum imports); at present, they serve environmental purposes [40]. According to the latest available dataset, in Romania, the energy tax accounts for 1.8\% of GDP and 5.8\% of total taxation [41]. Table 1 presents the descriptions of the variables used for carrying out the research in the current paper.

The results cover Romania, and the data are imported from the Eurostat database, consisting of the environmental taxes as a percentage of total GDP and as total tax revenue. The real GDP is expressed per capita. The explanatory variables of the research include, as in [30], the primary production of renewable energy (Ppre), domestic material consumption (DMC), final energy consumption of petroleum ( $F e c p)$, and total gross electricity generation (Tgeg) (all expressed per capita). Primary production of renewable energy is employed as a proxy for environmental subsidies, in tons of oil equivalent, as there are not sufficient and representative data on environmental subsidies for analysis. Table 1 includes the description of the variables used in the study. The series of data used has a length of 12 years, and it runs from 2000 to 2011, starting in 2000 as these are the earliest data available in the Eurostat database for all the complete variable datasets, and the summary statistics are presented in Table 2.

Table 1. Description of variables. Source: authors' own selection based on EUROSTAT database [41].

\begin{tabular}{cc}
\hline Variable & Description \\
\hline$Y$ & Real GDP per capita \\
Taxy & Total environment taxes to GDP (\%) \\
Taxye & Environmental taxes as \% of GDP-Energy \\
Taxt & Environmental taxes as \% of Total Taxation-Energy \\
I_taxe & Implicit tax rates-Energy \\
Taxypr & Environmental taxes as \% of GDP-Pollution resources \\
Ppre & Primary production of renewable energy per capita \\
DMC & Domestic material consumption per capita \\
Fecp & Final energy consumption of petroleum per capita \\
Tgeg & Total gross electricity generation per capita \\
\hline
\end{tabular}


Table 2. Data summary statistics based on the raw data.

\begin{tabular}{ccccccccccc}
\hline Statistics & $\boldsymbol{Y}$ & Taxy & I_taxe & Taxye & Taxt & Taxypr & Ppre & Tgeg & DMC & Fecp \\
\hline Mean & 3859.189 & 2.186136 & 52.69121 & 1.900517 & 6.746930 & 0.128970 & 0.214043 & 2.652599 & 16.91417 & 0.163907 \\
Median & 3900.000 & 2.034668 & 52.40125 & 1.766802 & 6.389863 & 0.103556 & 0.218385 & 2.691645 & 16.37000 & 0.164637 \\
Maximum & 4800.000 & 3.430490 & 68.75033 & 3.224650 & 10.67382 & 0.361268 & 0.262924 & 2.895884 & 26.83000 & 0.200175 \\
Minimum & 2760.667 & 1.779444 & 35.22194 & 1.408918 & 5.025840 & 0.006326 & 0.150526 & 2.367942 & 7.700000 & 0.125214 \\
Std. Dev. & 716.1577 & 0.439889 & 10.90903 & 0.458582 & 1.439085 & 0.132298 & 0.034606 & 0.183337 & 5.354503 & 0.023938 \\
Skewness & -0.212915 & 2.001134 & -0.166889 & 2.132977 & 1.750853 & 0.692123 & -0.515793 & -0.311396 & 0.132096 & -0.021466 \\
Kurtosis & 1.571094 & 6.489732 & 1.988086 & 7.061617 & 5.782362 & 2.032511 & 2.189466 & 1.696055 & 2.337197 & 1.764997 \\
Jarque-Bera & 1.111551 & 14.09819 & 0.567689 & 17.34755 & 10.00174 & 1.426087 & 0.860567 & 1.044071 & 0.254552 & 0.763538 \\
Probability & 0.573627 & 0.000868 & 0.752884 & 0.000171 & 0.006732 & 0.490150 & 0.650325 & 0.593312 & 0.880491 & 0.682653 \\
Sum & 46310.27 & 26.23363 & 632.2945 & 22.80621 & 80.96316 & 1.547637 & 2.568521 & 31.83118 & 202.9700 & 1.966886 \\
Sum Sq. Dev. & 5641700. & 2.128526 & 1309.076 & 2.313276 & 22.78064 & 0.192531 & 0.013173 & 0.369739 & 315.3777 & 0.006303 \\
Observations & 12 & 12 & 12 & 12 & 12 & 12 & 12 & 12 & 12 \\
\hline
\end{tabular}

\section{Research Methodology}

In this paper, the research methodology is designed based on Granger non-causality, starting from previous research studies [30,42-45]. Despite some technical differences, as remarked in some studies, the general approach of the Granger non-causality tests, either using time series or panel data, involves the application of cointegration techniques with the subsequent error correction model used to test short- and long-run causality $[16,29,30,38,44,45]$.

Also, the concept of Granger non-causality usually incorporates a number of related aspects such as cointegration, stability and controllability $[2,10,11,14,20]$. In applying the designed methodology, the first step routinely involves testing for a panel unit root using the Im Pesaran and Shin (IPS) test, as has been used in some previous researches $[1,30,33,46]$. If the variables are found to be $I(1)$, it is then necessary to test for cointegration, in this case the Granger test is employed. Applying the following research model:

$$
y_{t}=\alpha_{0}+\alpha_{1} x_{t}+\varepsilon_{t}
$$

where $y_{t}$ is GDP (expressed in logarithms), $\alpha_{0}, \alpha_{1}$ are parameters to be estimated in the study and $x_{t}$ is the exogenous variable considered (also if the causality testing runs in the opposite direction, $x_{t}$ would be considered the dependent variable).

In this case it is required further more to pre-test each variable considered in the model in order to show and determine the order of integration for each variable and highlight the best influence. By definition, any cointegration imposes the mandatory requirement that both variables of the same order be integrated. The common method employed for these cases is done using the Augmented Dickey-Fuller (ADF) unit root test in order to infer the number of unit roots (if any) in each of the variables under investigation $[30,45]$. The testing procedure for the ADF unit root test is used and applied to one of the following models [47]:

$$
\begin{gathered}
\Delta y_{t}=\gamma^{*} y_{t-1}+\sum_{j=1}^{p} \varphi_{j} y_{t-j}+\varepsilon_{t} \\
\Delta y_{t}=\alpha+\gamma^{*} y_{t-1}+\sum_{j=1}^{p} \varphi_{j} y_{t-j}+\varepsilon_{t} \\
\Delta y_{t}=\alpha+\beta t+\gamma^{*} y_{t-1}+\sum_{j=1}^{p} \varphi_{j} y_{t-j}+\varepsilon_{t}
\end{gathered}
$$

The two hypotheses of the test are according to literature definitions, as following [14]: $\mathrm{H}_{0}$ : $\gamma^{*}=0 \Leftrightarrow$ series is non-stationary and has a unit root; $\mathrm{H}_{1}: \gamma^{*}<0 \Leftrightarrow$ series is stationary and has no unit root. $\alpha$ is a constant; $\beta$ is the coefficient on a time trend series; $\gamma^{*}$ the coefficient of $y_{t-1} ; p$ is the lag order of the autoregressive process; $\Delta y_{t}=y_{t}-y_{t-1}$ are first differences of $y_{t} ; y_{t-1}$ are lagged values of order one of $y_{t} ; \Delta y_{t}$ are changes in lagged values; and $\varepsilon_{i t}$ is the white noise.

For the last specification, the test is done under the joint hypothesis $\beta=\gamma^{*}=0$. 
Once the hypothesis of the unit root test is rejected, the long-run equilibrium relationship is estimated in the form of an Ordinary Least Squares (OLS) regression line. If the variables cointegrate, the OLS regression equation yields a "super-consistent" estimator [47]. This means that there is a strong linear relationship between the variables under study. The strong linear relationship can be tested in either of the following ways [30]:

(a) The coefficient of $x_{t}$ yields a value that falls between 0.5 and 1 .

(b) The plot of $y_{t}$ against $x_{t}$ shows coordinates appearing in an increasing or decreasing direction. The next step is to estimate the error correction model (ECM) of the dynamic structure, starting from equation:

$$
y_{t}=\alpha_{0}+\gamma_{0} x_{t}+\gamma_{1} x_{t-1}+\alpha_{1} y_{t-1}+\varepsilon_{t}
$$

taking some algebraic manipulation as $[30,47]$ results:

$$
\begin{gathered}
\Delta y_{t}=\gamma_{0} \Delta x_{t}-\left(1-\alpha_{1}\right)\left[y_{t-1}-\frac{\alpha_{0}}{\left(1-\alpha_{1}\right)}-\frac{\left(\gamma_{0}+\gamma_{1}\right)}{\left(1-\alpha_{1}\right)} x_{t-1}\right]+\varepsilon_{t} \\
\text { Taking } \beta_{0}=\frac{\alpha_{0}}{\left(1-\alpha_{1}\right)} \text { and } \beta_{1}=\frac{\left(\gamma_{0}+\gamma_{1}\right)}{\left(1-\alpha_{1}\right)}
\end{gathered}
$$

the equation becomes

$$
\Delta y_{t}=\gamma_{0} \Delta x_{t}-\left(1-\alpha_{1}\right)\left(y_{t-1}-\beta_{0}-\beta_{1} x_{t-1}\right)+\varepsilon_{t}
$$

which is the ECM with $-\left(1-\alpha_{1}\right)$ as the speed of adjustment, and $\varepsilon_{t-1}=y_{t-1}-\beta_{0}-\beta_{1} x_{t-1}$ as the error-correction mechanism which measures the distance of the system from equilibrium. The coefficient of $\varepsilon_{t-1}$ should be negative in sign in order for the system to converge to equilibrium. The size of the coefficient $-\left(1-\alpha_{1}\right)$ is an indication of the speed of adjustment towards equilibrium in that [48]:

- small values of $-\left(1-\alpha_{1}\right)$, tending to -1 , indicate that economic agents remove a large percentage of disequilibrium in each period;

- larger values, tending toward 0 , indicate that adjustment is slow;

- $\quad$ extremely small values, less than -2 , indicate an overshooting of economic equilibrium;

- positive values would imply that the system diverges from the long-run equilibrium path.

Testing for cointegration is achieved using the Kao test $[30,48]$ based on a version of the ADF test on the residual $\left(\varepsilon_{t}\right)$ of Equation (1):

$$
\varepsilon_{t}=\rho \varepsilon_{t-1}+\sum_{j=1}^{p} \lambda_{j} \Delta \varepsilon_{t-j}+v_{t}
$$

This is further used to develop the following form of the ADF statistic as it is shown by the line described by Equation (3), which is a one tailed test and where $\hat{\sigma}_{v}^{2}$ is the estimated variance and $\hat{\sigma}_{0 v}^{2}$ is the estimated long-run variance of the error term and follows the parameters of the standard normal distribution [14,30]. Also, the $\tau_{A D F}$ is the ADF statistic designed in Equation (8) [30]:

$$
A D F=\frac{\tau_{A D F}+\sqrt{6 N} \hat{\sigma}_{v} /\left(2 \hat{\sigma}_{0 v}\right)}{\sqrt{\hat{\sigma}_{0 v}^{2} /\left(\hat{\sigma}_{v}^{2}\right)+3 \hat{\sigma}_{v}^{2} /\left(10 \hat{\sigma}_{0 v}^{2}\right)}}
$$


The final research is conducted using the OLS method and employing the following empirical model:

$$
\begin{gathered}
y_{t}=\beta_{0}+\beta_{1} \text { Taxy }+\beta_{2} \text { Taxye }+\beta_{3} \text { Taxt }+\beta_{4} \Delta I_{-} \text {taxe }+\beta_{5} \text { Taxypr } \\
+\beta_{6} \text { Ppre }+\beta_{7} \text { DMC }+\beta_{8} \text { Fec } p+\beta_{9} \text { Tgeg }+\varepsilon_{t}
\end{gathered}
$$

where $y_{t}$ is the logarithm of the real per capita GDP; as series Taxy, Taxye, Taxt and Taxypr are stationary (see IPS unit root test-Table 4), they are used as such; the other series have been stationarized as follows: $\Delta I_{-}$taxe is the first-order difference of the I_taxe; and for the series Ppre, $D M C, F e c p$, and Tgeg the annual percentage changes were considered.

\section{Results and Discussion}

In order to evidence the causal relationship between the Romanian GDP and several explanatory variables related to taxation of environmental damage and energy generation and consumption in Romania, some statistical tests were carried out for the data employed in the study. The results for the IPS panel unit root tests are presented in Table 3 and show that, except for environmental taxes on GDP, environmental taxes as \% of GDP (energy) and environmental taxes as \% of total taxation (energy and pollution resources), the variables contain a unit root, suggesting the need to differentiate these variables before testing for non-causality.

Table 3. IPS unit root tests.

\begin{tabular}{ccc}
\hline Variable & Level & Differenced \\
\hline$Y$ & -1.2833 & $-2.6897^{* * *}$ \\
Taxy & $-5.8591^{* * *}$ & $-5.3437^{* * *}$ \\
Taxi & -1.1290 & $-5.0960^{* * *}$ \\
Taxye & $-6.4893^{* * *}$ & $-4.0979^{* *}$ \\
Taxt & $-5.0750^{* * *}$ & $-3.9825^{* *}$ \\
Taxypr & $-2.7870^{*}$ & $-5.7531^{* * *}$ \\
Ppre & -1.8994 & $-3.8708^{* *}$ \\
Tgeg & -1.7476 & $-4.2807^{* *}$ \\
DMC & -1.6525 & $-3.4231^{* *}$ \\
Fecp & -1.0655 & $-3.2733^{* *}$ \\
\hline
\end{tabular}

Notes: Lag length is determined by the modified Akaike Information Criteria. ${ }^{*},{ }^{* *},{ }^{* * *}$ indicates the significance at $1 \%, 5 \%, 10 \%$ levels (one tailed test).

The cointegration tests for the considered dataset are contained in Table 4. It was tested for cointegration in both directions, with both variables acting as the dependent variable.

The Kao test for cointegration results shows evidence of a stable long-run cointegrating relationship when the taxes are the dependent variable and they are considered as a proportion of GDP. However, there is evidence of a stable long-run relationship between GDP, as the dependent variable, and total gross electricity generation, consistent with other researches [30,38].

Based on the results obtained during the research, it can be remarked that, despite some evidence of a stable long-run relationship when the taxes are the dependent variable of the model, there is no evidence showing when GDP becomes the dependent variable. So, using the Granger method, where there is evidence of cointegration, the error correction term will be included in the non-causality tests, but excluded where there is no evidence [49-51]. 
Table 4. Tests for cointegration.

\begin{tabular}{ccc}
\hline Test Statistic & $\mathbf{X} \rightarrow \mathbf{Y}$ & $\mathbf{Y} \rightarrow \mathbf{X}$ \\
\hline Y/Taxy & 0.24691 & $5.33313^{* *}$ \\
Y/Taxi & 0.53319 & $5.26506^{* *}$ \\
Y/Taxye & 0.19499 & $5.36005^{* *}$ \\
Y/Taxt & 0.05136 & $4.50340^{* *}$ \\
Y/Taxypr & 1.65858 & 0.20420 \\
Y/Ppre & 0.07900 & $6.24810^{* *}$ \\
Y/Tgeg & $9.83934^{* *}$ & $0.08716^{* *}$ \\
Y/DMC & 4.27421 & $6.23856^{* *}$ \\
Y/Fecp & 2.67204 & $4.82740^{* *}$ \\
\hline
\end{tabular}

Notes: In the first and second columns, the dependent variable in the cointegrating relation is first followed by the explanatory variable. ${ }^{* *}$ Indicates rejection of the null hypothesis of no cointegration at the $5 \%$ level of significance.

Table 5 contains the results from the ECM estimation. These results are, in the long-run, despite the significance of estimated coefficients, outstanding and statistically relevant-in fact, overshooting influences tending to equilibrium from economic growth to primary production of renewable energy and final energy consumption of petroleum. Conversely, regarding the long-term causal effect from these variables on economic growth despite significance, the negative values of the coefficients, far less than above [52-56], indicate their reduced influence towards the economic growth. In case of the remaining variables, the long-term causal results show their divergence in both directions with economic growth. This is consistent with other previous studies in the field where either little or ambiguous evidence was discovered of the energy taxes' influence on economic growth $[10,11,33,34]$.

Table 5. Granger causality tests.

\begin{tabular}{ccccc}
\hline $\begin{array}{c}\text { Causality } \\
\text { Direction }\end{array}$ & ECT (t-Statistic) & $\begin{array}{c}\text { Speed of Adjustment } \\
(\boldsymbol{t} \text {-Statistic) }\end{array}$ & $\begin{array}{c}\text { Lag Coefficient } \\
(\boldsymbol{t} \text {-Statistic) }\end{array}$ & F-Statistic \\
\hline$Y \rightarrow$ Itaxe & $0.0153(13.622)^{* *}$ & $-0.012(-0.326)$ & $0.001(0.315)$ & 0.392 \\
Itaxe $\rightarrow Y$ & $6.539(7.036)^{* *}$ & $-0.970(-9.928)^{* *}$ & $-89.444(-6.216)^{* *}$ & $38.622^{* *}$ \\
$Y \rightarrow$ Ppre & $-45.57(-16.665)^{* *}$ & $0.342(0.798)$ & $-0.0787(-0.047)$ & 0.813 \\
$P p r e \rightarrow Y$ & $-0.0219(-17.038)^{* *}$ & $-0.889(-7.887)^{* *}$ & $0.226(4.837)^{* *}$ & $55.229^{* *}$ \\
$Y \rightarrow$ Tgeg & $0.686(0.736)$ & $-0.107(-0.965)$ & $0.339(1.690)$ & 1.542 \\
$T g e g \rightarrow Y$ & $1.457(3.280)^{* *}$ & $-0.109(-0.494)$ & $7.184(3.626)^{* *}$ & $11.260^{* *}$ \\
$Y \rightarrow D M C$ & $0.100(3.52)^{* *}$ & $-2.207(-3.623)^{* *}$ & $0.006(1.087)$ & $5.830^{* *}$ \\
$D M C \rightarrow Y$ & $9.966(4.271)^{* *}$ & $-0120(-0.317)$ & $-105.237(-2.63)^{* *}$ & $5.017^{* *}$ \\
$Y \rightarrow$ Fecp & $-35.356(-15.913)^{* *}$ & $0.560(0.647)$ & $1.157(0.465)$ & 2.712 \\
$F e c p \rightarrow Y$ & $-0.028(-18.769)^{* *}$ & $1.356(7.197)^{* *}$ & $0.673(10.264)^{* *}$ & $39.697^{* *}$ \\
\hline
\end{tabular}

** Indicates that $t$ it is significantly different to 0 at the $5 \%$ level of significance.

Nevertheless, the short-run causality results indicate convergence and significant results from implicit tax rates regarding energy and primary production of renewable energy and effects economic growth, the speed of adjustment being from $88 \%$ to $97 \%$ of adjustment back to the long-run in a year. Also, the results offer evidence of overshooting short-term equilibrium from economic growth to domestic material consumption.

As in other studies $[11,30]$ evidence supports Granger causality from renewable energy, proxying environmental subsidies to economic growth, although it is negatively signed, suggesting that expenditure on environmental protection as yet has not produced the technological spillovers and subsequent increase in growth. Finally, taking into account the IPS test results, the results yielded from OLS regression for the considered model are presented in Table 6. 
Table 6. OLS regression results (ordinary least square).

\begin{tabular}{cc}
\hline Variable & Coefficient \\
\hline Constant & $8.256(1557.8)^{* * *}$ \\
Taxy & $0.345(65.7)^{* * *}$ \\
Taxye & $-0.479(-49.7)^{* * *}$ \\
Taxt & $0.052(19.8)^{* *}$ \\
Taxypr & $-1.301(-394.1)^{* * *}$ \\
Ppre & $0.001(18.4)^{* *}$ \\
DMC & $-0.001(-57.2)^{* * *}$ \\
Fecp & $0.001(33.5)^{* * *}$ \\
Tgeg & $-0.001(-130.2)^{* * *}$ \\
F-statistic & $97777.14^{* * *}$
\end{tabular}

Note: the values in round brackets are the $t$-statistics. ${ }^{* *},{ }^{* * *}$ indicate the coefficients which are statistically significant at $5 \%$, and $10 \%$, respectively. F-statistics are reported to test for the joint significance of the coefficients.

Despite the difficulties induced by the model specification in direct interpretation of the results (Table 6), they indicate that all the considered variables exert significant influence on economic growth, direct correlated with total environment taxes to GDP, environmental taxes as \% of total taxation-energy, primary production of renewable energy, and final energy consumption of petroleum. Nevertheless the results indicate a negative relation between the economic growth and environmental taxes as \% of GDP-energy, environmental taxes as \% of GDP-pollution resources, domestic material consumption and total gross electricity generation [30].

\section{Research Limits and Future Directions for Research}

From the methodological point of view, the most important limitation is represented by the relative shortness of the time series used, as these data for Romania are collected beginning in 2000. Through this paper, the authors tried to evaluate the evolutions in the field under research in an emergent economy-specific context. On the other hand, we did not take into account the assessment of possible effects of energy tax policy on greenhouse emissions and to what extent these measures can contribute to the internalization of these issues, which will be researched in future studies.

\section{Conclusions}

The results obtained during this research provide solid ground for the long-run causal effect on GDP due to the variables considered and used to demonstrate the influence on achieving the sustainable development criteria in an emergent economy, as in the case of Romania. The pertinent design of the environmental taxation system represents one of the determinant objectives for inland policymakers, taking into consideration that during the analyzed period the importance of environmental revenues has increased both as gross values and share of GDP [57]. Also, for an emergent economy, it is important for policy makers to discover the relationship between GDP and environmental taxation's influence in assuring welfare, because these final results in research can certainly help in proper design and imposition of energy policy. This paper has clearly communicated from the very beginning that this objective may represent an important output for policymakers.

The policy implications of this study are transversely connected. Environmental taxation is just a lever for assuring environmental protection and sustainable development. Environmental taxation has a quite decisive influence on the economy by influencing the consumption patterns, despite the fact that there is no direct connection between living standard, environmental protection, and degree of green freedom. For emergent economies, environmental taxation may represent a path to achieving sustainable development and a high degree of green revenues by taxing pollutants and promoting environmental friendly practices and technologies.

In order to ensure the effectiveness of the energy tax policy, a dual application both in the short and long term may represent a suitable solution. As in the short term, a paradigm shift in the use 
of energy resources is impossible, the classic fiscal measures imposed must envisage the taxation of energy overconsumption and of heavily polluting energy products [58]. This design of energy taxation is aimed specifically at reduction and partial replacement of the latter products with renewable energy products [56,59]; in the long-run, the fiscal measures should favor investments in the promotion of new energy efficient technologies.

Author Contributions: This paper is the result of the joint work by all the authors. Jean Andrei wrote the introduction and part of the conclusions, Mihai Mieila designed the methodology and carried out the formal and econometrical analysis and discussion, Gheorghe H. Popescu and Elvira Nica supervised the project and writing and data curation and provided funding acquisition and Manole Cristina double-checked the English writing. All authors have discussed and agreed to submit the manuscript.

Conflicts of Interest: The authors declare no conflict of interest.

\section{References}

1. Hasselknippe, H.; Christiansen, A.C. Energy Taxation in Europe: Current Status-Drivers and Barriers-Future Prospects; Report 14/2003; Fridtjof Hansen Inst.: Lysaker, Norway, 2003.

2. Heine, D.; Norregaard, J.; Parry, I.W.H. Environmental Tax Reform: Principles from Theory and Practice to Date; IMF Working Paper, WP/12/180; International Monetary Fund: Washington, DC, USA, 2012.

3. Popescu, G.H. ICT's Potential in Reducing GHG Emissions through Sustainable Manufacturing Technologies. J. Self-Gov. Manag. Econ. 2015, 3, 66-71.

4. Datta, A. The incidence of fuel taxation in India. Energy Econ. 2010, 32, S26-S33. [CrossRef]

5. Popescu, G.H. Sustainability, Public Health, and Quality of Care. Am. J. Med. Res. 2015, 2, 211-216.

6. Viegas, C.V.; Bond, A.; Ribeiro, J.L.D.; Selig, P.M. A review of environmental monitoring and auditing in the context of risk: Unveiling the extent of a confused relationship. J. Clean. Prod. 2013, 47, 165-173. [CrossRef]

7. Aldy, J.E.; Ley, E.; Parry, I. A tax-based approach to slowing global climate change. Natl. Tax J. 2008, 61, 493-517. [CrossRef]

8. Baranzini, A.; Goldemberg, J.; Speck, S. A future for carbon taxes. Ecol. Econ. 2000, 32, 395-412. [CrossRef]

9. Nica, E. ICT Innovation, Internet Sustainability, and Economic Development. J. Self-Gov. Manag. Econ. 2015, 3, 24-29.

10. Jeffrey, C.; Perkins, J.D. The Impact of Energy Taxes on Carbon Dioxide Emissions in the European Union; Working Paper; Iowa State University: Iowa, IA, USA, 2013.

11. Jeffrey, C.; Perkins, J.D. The association between energy taxation, participation in an emissions trading system, and the intensity of carbon dioxide emissions in the European Union. Int. J. Account. 2015, 50, 397-417. [CrossRef]

12. Van Heerden, J.; Gerlagh, R.; Blignaut, J.; Horridge, M.; Hess, S.; Mabugu, R.; Mabugu, M. Searching for triple dividends in South Africa: Fighting $\mathrm{CO}_{2}$ pollution and poverty while promoting growth. Energy J. 2006, 27, 113-141. [CrossRef]

13. Ambec, S.; Cohen, M.A.; Elgie, S.; Lanoie, P. The Porter Hypothesis at 20: Can environmental regulation enhance innovation and competitiveness? Rev. Environ. Econ. Policy 2013, 7, 2-22. [CrossRef]

14. Bjertbaes, G.H.; Faehn, T. Energy taxation in a small, open economy: Social efficiency gains versus industrial concerns. Energy Econ. 2008, 30, 2050-2071. [CrossRef]

15. Bovenberg, A.; De Mooij, R. Environmental taxes, international capital mobility and inefficient tax systems: Tax burden versus tax shifting. Int. Tax Public Financ. 1998, 5, 7-39.

16. Ciaschini, M.; Pretaroli, R.; Severini, F.; Socci, C. Regional double dividend from environmental tax reform: An application for the Italian economy. Res. Econ. 2012, 66, 273-283. [CrossRef]

17. Kosonen, K.; Nicodème, G. The Role of Fiscal Instruments in Environmental Policy; European Commission's Directorate-General for Taxation and Customs Union Office for Official Publications of the European Communities: Luxembourg, 2009.

18. Labandeira, X.; Labeaga, J.M.; Rodriguez, M. An integrated economic and distributional analysis of energy policies. Energy Policy 2009, 37, 5776-5786. [CrossRef]

19. Sterner, T.; Lozada, A.L. Income Distribution Effects of Fuel Taxation; Environmental Economics Unit, Department of Economics, University of Gothenburg: Gothenburg, Sweden, 2009. 
20. Eurostat. Taxation trends in the European Union. Data for the EU Member States, Iceland and Norway; Office for Official Publications of the European Communities: Luxembourg, 2015.

21. Shahbaz, M.; Mutascu, M.; Azim, P. Environmental Kuznets curve in Romania and the role of energy consumption. Renew. Sustain. Energy Rev. 2013, 18, 165-173. [CrossRef]

22. Pigou, A.C. The Economics of Welfare; Macmillan: London, UK, 1920.

23. Steininger, K.W.; Friedl, B.; Gebetsroither, B. Sustainability impacts of car road pricing: A computable general equilibrium analysis for Austria. Ecol. Econ. 2007, 63, 59-69. [CrossRef]

24. Stamatova, S.; Steurer, A. Environmental Taxes—Detailed Analysis. Environmental Taxes Account for $6.17 \%$ of All Revenues from Taxes and Social Contributions in the EU-27 in 2011, Statistics in Focus 26/2013; EUROSTAT: Luxembourg, 2013.

25. Bye, T.; Bruvoll, A. Taxing Energy —Why and How? The Present Policies across Western Countries; Statistics Norway: Oslo, Norway, 2008.

26. Lazaroiu, G. The Role of the Management Consultancy Industry in the Knowledge Economy. Psychosoc. Issues Hum. Res. Manag. 2015, 3, 71-76.

27. Popescu, G.H. The Competitive Nature and Effectiveness of Online Retailing. Psychosoc. Issues Hum. Res. Manag. 2015, 3, 101-106.

28. Nanthakumar, L.; Muhammad, S.; Roshaiza, T. The link between green taxation and economic growth on $\mathrm{CO}_{2}$ emissions: Fresh evidence from Malaysia. Renew. Sustain. Energy Rev. 2014, 38, 1083-1091.

29. Genty, A.; Arto, I.; Neuwahl, F. Final Database of Environmental Satellite Accounts: Technical Report on Their Compilation. WIOD Documentation 4.6. Available online: http://www.wiod.org/publications/ source_docs/Environmental_Sources.pdf (accessed on 7 December 2014).

30. Abdullah, S.; Morley, B. Environmental taxes and economic growth: Evidence from panel causality tests. Energy Econ. 2014, 42, 27-33. [CrossRef]

31. Ozturk, I.; Bilgili, F. Economic growth and biomass consumption nexus: Dynamic panel analysis for Sub-Sahara African countries. Appl. Energy 2015, 137, 110-116. [CrossRef]

32. Jeffrey, C.; Perkins, J.D. The Relationship between Energy Taxation and Business Environmental Protection Expenditures in the European Union. Int. J. Account. 2014, 49, 403-425. [CrossRef]

33. Li, A.; Lin, B. Comparing climate policies to reduce carbon emissions in China. Energy Policy 2013, 60, 667-674. [CrossRef]

34. Mishra, V.; Sharma, S.; Smyth, R. Are fluctuations in energy consumption per capita transitory? Evidence from a panel of Pacific Island countries. Energy Policy 2009, 37, 2318-2326. [CrossRef]

35. Popescu, G.H. Sustainable Development and the Implementation of Citizen-oriented Services. J. Self-Gov. Manag. Econ. 2015, 3, 70-78.

36. Eurostat. Environmental Taxes-A Statistical Guide; Office for Official Publications of the European Communities: Luxembourg, 2001.

37. Filipovi, S.; Golusin, M. Environmental taxation policy in the EU-New methodology approach. J. Clean. Prod. 2015, 88, 308-317. [CrossRef]

38. Harper, C.K. Climate change and tax policy. Boston Coll. Int. Comp. Law Rev. 2007, 30, 411-460.

39. Kao, C. Spurious Regression and Residual-Based Tests for Cointegration in Panel Data. J. Econ. 1999, 90, 1-44. [CrossRef]

40. Davoust, R. Gasoline and Diesel Prices and Taxes in Industrialized Countries; Ifri: Paris, France, 2008.

41. Eurostat, Eurostatdatabase. 2016. Available online: http:/ / ec.europa.eu/eurostat/data/database (accessed on 27 October 2014).

42. Constantini, V.; Martini, C. The causality between energy consumption and economic growth: Amultisectoral analysis using non-stationary cointegrated data. Energy Econ. 2010, 32, 591-603. [CrossRef]

43. Timilsina, G.R. Oil prices and the global economy: A general equilibrium analysis. Energy Econ. 2015, 49, 669-675. [CrossRef]

44. Brooks, T. Climate change justice through taxation? Clim. Chang. 2015, 3, 419-426. [CrossRef]

45. Granger, C. Some recent development in the concept of causality. J. Econ. 1988, 39, 199-211. [CrossRef]

46. Breitung, J.; Pesaran, M.H. Unit roots and cointegration in panels. In The Econometrics of Panel Data; Springer: Berlin, Germany, 2008; pp. 279-322.

47. Enders, W. Applied Econometric Time Series; Wiley: New York, NY, USA, 2004.

48. Greene, W.H. Econométrie, 7th ed.; Pearson Education France: Paris, France, 2011; p. 958. 
49. Zietlow, K.J. What Is Left Today? Analyzing OPEC's Influence on the Crude Oil Price. J. Self-Gov. Manag. Econ. 2015, 3, 61-69.

50. Narayan, P.K.; Narayan, S.; Smyth, R. Are oil shocks permanent or temporary? Panel data evidence from crude oil and NGL production in 60 countries. Energy Econ. 2008, 30, 919-936. [CrossRef]

51. Lanoie, P.; Laurent-Lucchetti, J.; Johnstone, N.; Ambec, S. Environmental policy, innovation and performance: New insights on the Porter Hypothesis. J. Econ. Manag. Strategy 2011, 20, 803-842. [CrossRef]

52. Dickson, R. Using Tax Policy to Build our Economy and Clean Our Environment. Posted in the Newsletter of America's Program of the Center for International Policy. 2 February 2007. Available online: http: //www.cipamericas.org/archives/1202 (accessed on 26 October 2016).

53. Santos, G.; Catchesides, T. Distributional Consequences of Gasoline Taxation in the United Kingdom. Transp. Res. Rec. J. Transp. Res. Board 2005, 1924, 103-111. [CrossRef]

54. El-Montasser, G.; Gupta, R.; Smithers, D. Convergence of Per Capita Income: The Case of U.S. Metropolitan Statistical Areas. Econ. Manag. Financ. Mark. 2016, 11, 11-32.

55. West, S.E. Distributional effects of alternative vehicle pollution control policies. J. Public Econ. 2004, 88, 735-757. [CrossRef]

56. Zeineb, A.; Rashid, A.M.; Alammari, A.G. Review of policies encouraging renewable energy integration \& best practices. Renew. Sustain. Energy Rev. 2015, 45, 249-262.

57. Popescu, G.H. The Dynamics of Social Innovation Networks. Psychosoc. Issues Hum. Res. Manag. 2015, 3, 77-82.

58. Mulligan, C.B. The Impact of Health Reform on Employment and Work Schedules. Am. J. Med. Res. 2015, 2,5-40.

59. Kamil, K. Energy and environmental issues relating to greenhouse gas emissions for sustainable development in Turkey. Renew. Sustain. Energy Rev. 2009, 13, 253-270.

(C) 2016 by the authors; licensee MDPI, Basel, Switzerland. This article is an open access article distributed under the terms and conditions of the Creative Commons Attribution (CC-BY) license (http://creativecommons.org/licenses/by/4.0/). 